\title{
THE RISK OF FINANCIAL NETWORKS \\ IN THE CONTEXT OF CURRENT CHALLENGES
}

\author{
Otilia MANTA1, PhD in Economics \\ Center for Financial and Monetary Research \\ „Victor Slavescu”, Romanian Academy
}

DOI: https://doi.org/10.36004/nier.es.2019.2-04

JEL Classification: F17, G15, G23, G29, 016

UDC: 330.131.7:336]:004

\section{ABSTRACT}

In the current context of the redefinition of financial markets due to the challenges generated by the multi-polarity phenomenon, virtual space becomes the main trading place for financial products, and our role as a researcher is to identify new financial instruments appropriate to this reality, which is why we consider that a market trend financial is that of a new network architecture in the virtual financial space based on nodes of financial interference. Moreover, financial space is a monetary representation of all other areas that can be identified and defined in society, especially in the economy, and can be considered as a set of specific financial interconnections with defining characteristics that determine them. Along with the profound changes in the interconnection of the socio-economic entities, using the new information channels, more and more often in the discussions of the specialists and not only a number of monetary issues are debated, in its virtual aspect, respectively the financial risks related to the virtual space, as well as the degree of "mastery" of information networks. In this context, in this paper we will try to make a series of contributions on how this financial space is designed - as a complex network with an adequate degree of risk.

Keywords: finance, financial network, digitization, financial risk and sustainability.

În contextul actual al redefinirii piețelor financiare urmare a provocărilor generate de fenomenul multipolaritate, spațiul virtual devine principalul loc de tranzacționare al produselor financiare, iar rolul nostru de cercetător este să identificăm noi instrumente financiare adecvate acestei realități, motiv pentru care considerăm că o tendință a piețelor financiare este aceea ca a unei noi arhitecturi de tip rețea din spațiul financiar virtual, bazată pe noduri de interferență financiară. Mai mult, spațiul financiar este o reprezentare monetară a tuturor celorlalte domenii care pot fi identificate și definite în societate, în special în economie, și pot fi considerate ca un set de interconexiuni financiare specifice cu caracteristici definitorii care le delimitează. Alături de schimbările profunde în interconectarea entităților socio-economice, folosind noile canale de informare, din ce în ce mai des în discuțiile specialiștilor și nu numai se dezbat o serie de probleme monetare, în aspectul său virtual, respectiv riscurile financiare legate de spațiul virtual, precum și gradul de „stăpânire” al rețelelor de informații. În acest context, în această lucrare vom încerca să aducem o serie de contribuții asupra modului în care este conceput acest spațiu financiar - ca o rețea complexă cu un grad adecvat de risc.

Cuvinte-cheie: finanțe, rețea financiară, digitalizare, risc financiar și durabilitate.

В нынешнем контексте переопределения финансовых рынков из-за проблем, порождаемых феноменом многополярности, виртуальное пространство становится основным местом торговли финансовыми продуктами, и наша роль как исследователя заключается в выявлении новых финансовых инструментов, соответствующих этой реальности, поэтому мы считаем, что тенденция финансовых рынков - это новая сетевая архитектура в виртуальном финансовом пространстве, основанная на узлах финансового вмешательства. Кроме того, финансовое пространство представляет собой денежное представление всех других областей, которые могут быть выявлены и определены в обществе, особенно вэкономике, и могут рассматриваться как набор

1 C Otilia MANTA, otilia.manta@rgic.ro, otilia.manta@icfm.ro

No. 2 / 2019 
конкретных финансовых взаимосвязей с определяющими их характеристиками. Наряду с глубокими изменениями во взаимосвязи социально-экономических субъектов, использующих новые информационные каналы, все чаще и чаще в дискуссиях специалистов обсуждается не только ряд денежных вопросов, в виртуальном аспекте, соответственно, финансовые риски, связанные с виртуальным пространством, а также степень «владения» информационными сетями. В этом контексте, в статье рассматривается устройство этого финансового пространства, как сложной сети с адекватной степенью риска.

Ключевые слова: финансы, финансовая сеть, оцифровка, финансовый риск и устойчивость.

INTRODUCTION. The financial market is a network of relationships made up of institutions, flows and instruments that ensure the transfer of financial assets and goods (currency and its substitutes) from one economic subject to another, which is realized, directly or indirectly, punctually or cumulatively.

The created financial flows between economic subjects (accounting organizations, institutions) forms financial circuits where the currency can take different forms of financial assets between two consecutive exchanges (sale or purchase) of commodity. Financial circuits, which constitute money transfer channels, carry the currency of payment, saving currency, placement currency, speculative currency, reserve currency, hedging currency, etc., by activating, balancing, valuing, distributing, multiplying the currency, creating a multiplicity and diversity of financial markets, interconnected and integrated into a network.

The main working hypotheses in this article are:

I1. The financial circuit may be represented in the network;

I2. The financial markets within the network are integrated;

I3. Flawless links between risks and performance in financial networks are created.

Relating from the first working hypothesis the financial circuit can be represented as follows:

where:

$$
S_{1} \wedge A_{1} \wedge A_{2} \wedge A_{3} \wedge A_{4} \wedge S_{2}
$$

S1, S2 - commodity-money exchange;

$\mathrm{A} 1, \mathrm{~A} 2, \mathrm{~A} 3, \mathrm{~A} 4$ - currency flows as a financial asset;

The financial markets within the network are integrated, ie they include and intersect, reunite and influence, forming a functional unit through a variety of forms.

Financial Markets include the following forms:

- the settlement, payment and payment markets;

- the credit market, which transfers currency by transformation and monetary creation;

- the deposit market, collection by concentration and depersonalization of the currency.

These three forms (segments, components) form the bank market, in its original meaning.

- the money market, with its defining component, the interbank market, to which the central bank, administered by the central bank, is transferred, the currency that forms the basis (primary source) of financial flows;

- the financial securities market, ie debts (liabilities, commitments) written in short-term maturity $(<1$ year);

- the securities, stocks and bonds market, with long-term maturity, called the capital market;

- the hedging market, derivatives that represent hedging contracts;

- the currency market, on which national currencies (currencies) are changed.

These eight forms of the financial market can be found, depending on the nature and content of financial instruments (support of financial assets, currency), in a diversity of hypostases, the financial market segmenting and assimilation, customization and uniformity -they, forming, as I said, a unity in diversity.

\section{RESEARCH METHODOLOGY}

As research methodology, we used classical observation and examination instruments, research methods based on the basic principles of scientific research, namely: "competence, objectivity, truth, methodical, demonstration, correlation, evaluation of results, utility and psychomoral "(Ristea and Franc, 2013). Procedures based on factual analysis, intensive documentation at 
the level of domestic and international literature, using the databases and the scientific material existing in the endowment of libraries of specific institutes in Romania and internationally, have been used. The methodology of the paper has as a direct instrument the collection of data and information from the literature and from the existing practice in public and private institutions, but especially scientific articles published on specialized research networks (ResearchGate, Academia.edu, etc.), published articles in various journals, relevant books in the field of reference, legislation, analyzes and studies, official documents, and interactive database of the National Bank of Romania, other relevant sources identified in the libraries: CCFM, Romanian Academy, INCE, IEN, BNR, National Library, INS, etc. Moreover, we analyzed the documents using the comparative, analytical, descriptive method, the nonparticipative and participatory observation, the use of a set of informational sources, the collection of financial data in the established databases. Also, the paper was based on annual reports, publications, consolidated statistical data provided by the European Commission, the National Bank of Romania, the European Central Bank (ECB), the International Settlement Bank (BRI), the European Commission, OECD, published annually. have been processed in order to provide an overall and analytical picture of the most important changes taking place in the European Union as a whole, but also globally - considered to be representative of the understanding of the phenomena studied, and especially in Romania.

\section{RESEARCH RESULTS}

The financial space is dual, presenting two often contradictory hypostases: the totality of entities, channels, stocks and collection streams, on the one hand, and all entities, channels, stocks and placement flows on another hand. In this context, we propose to analyze the components of the financial network and a better delimitation of the risks that may arise in such types of networks.

Any company, in order to achieve its short, medium or long term goals, interacts with its social, economic, natural environment. From a financial point of view, the company's relationship with its environment can be formalized by appealing to the concept of financial network. In this way, a financial structure at micro, meso or macroeconomic level can be reflected, identifying the interconnections between autonomous entities, recognized and identified legally, economically and socially. On the other hand, the financial space is a monetary representation of all other areas that can be identified and defined in society, particularly in the economy, and can be considered as a set of specific financial interconnections with defining features that delimit them.

Network risk (RRT) takes on concrete forms of action, manifestations, typically determined by the characteristics of the network that are affected by the decoupling, distortion, phasing out, distortion, weakening of the strength of a financial network feature. Obviously, these forms refer to the radiant impact of the institutional characteristic of the network, embodied in norms, bodies, rules, structures, etc. on the interactive features of the network. The institutional grid of the network is the force, the ability of the interactive feature of the network to negatively influence the performance of the components ${ }^{1}$.

Based on these considerations, the global risk of financial networks needs to be assessed in the current context of challenges in terms of the functionality of the financial network principle.

The complex relationship in which the network risk acts on the performance, the goals, the functionalities and the potentialities of the network is presented in figure 1, in the form of an impulse relathionship, justification of working hypothesis 3, respectively flawless links between risks and performance in financial networks.

\footnotetext{
1 Mihail D., Manta O. (2017): Architecture of Flows and Financial Stocks - Mechanism and Transmission Channels, Flow, Transmitters and Receivers, published in Advances in Intelligent Systems Research, volume 132, Atlantis Press.
} 


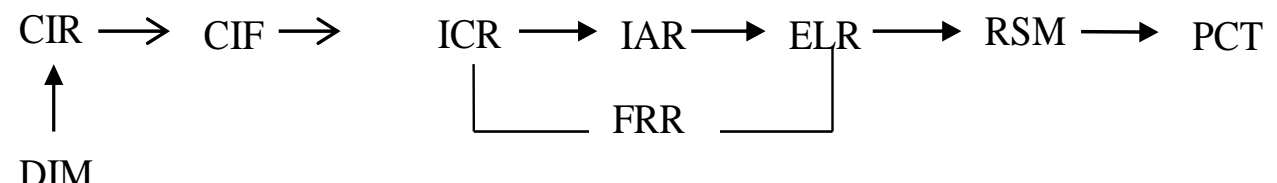

Figure 1. Impulse relationships between risks and performance

The meaning of the symbols is the following:

- DIM = institutional deficiencies of the financial network;

- $\mathrm{CIR}=$ the institutional feature of the network;

- $\mathrm{CIF}=$ interactive features of the network;

- ICR = network interconnections;

- IAR = network interactions (interactive flows;

- ELR = network elements;

- FRR = network risk forms;

- $\mathrm{RSM}=$ risks specific to the financial network;

- $\mathrm{PCT}=$ losses and costs.

The forms of network risk are as follows:

- The credibility risk is the essential form of risk of the financial network, mitigating or distorting the trust of the economic subjects in the currency, financial instruments, financial-monetary institutions, due to the malfunctions, directly or indirectly induced by contagion, immediate or delayed, with a time lag, all the specific risks and, first, the risk of depreciation of the currency.

Financial networks are irreducible to purely economic reasoning centered on earningsoriented economic interest, money transactions, operations and financial flows, relying on the trust of entities, economic subjects in the financial network, the transaction network, the fiduciary dimension being vital to the reproducibility of networks and for their continuity over time. Trust is an integral part of maintaining interconnections and interactive financial flows, especially taking into account the uncertainty and complexity of transactions.

Winning economic rationality does not cover the space of confidence in the currency, depending on different factors, economic rationality depending on individual, selfish, competing and confronted interests on the market, while trust is conditioned by coexistence, social, political, cultural, but also economic, trusting reciprocity, while economic rationality involves exclusion through competition (even if the market harmonizes gains through interests).

Trust is an essential property of the coin, an abstract feature of money in general, which does not imply the stability and validity of the concrete forms of the currency, since confidence in the stability and validity of a monetary form, a financial instrument, means trust in institutions and rules, and rules are directly responsible for the administration of this form of currency. In this respect, the nature of the risks involved in financial transactions, in interactive flows, reflects their unique character in the modern world, namely that they are generated by man-made institutions.

It can be argued that the credibility risk is not associated with trust in money as a social institution, but with confidence in social institutions, ie regulations and organizations, which create and administer specific monetary forms, financial instruments traded on the markets.

The credibility risk in the financial system is determined by economic, but especially extraeconomic conditions, the placement of monetary forms in an environment centered on economic rationality, the dependence of financial transactions, the interactivity of the financial network of interests and economic gain distorts and vices the functions of the currency, its transitive potential, the goals of the network, assuring the concrete forms of the coin of improper, adverse and unfavorable finiteities and functionalities. In this respect, speculative or derivative financial forms, as quaternary, forward-looking currencies, are at the same time extreme forms of risk credibility, generating risk, covering it [4, SHAPIRO, Carl et al., 1998].

- Vulnerability risk is a generic risk of the financial network, due to the inadequate, institutionally 
caused, flow characteristics and financial network, such as reliability, complexity, integration, intensity, connectivity, affecting the network as a whole, but differentiated on elements, interconnections and interactions.

Vulnerability expresses the debilitating of the transitive potential of the interactive flows of the network, favoring the emergence of specific risks, such as exchange rate risk, currency depreciation, interest rate risk, market risk, especially through the inadequacy channel and the inactivation channel.

The organizational inconsistency of the financial network, the inconsistency of the financial instruments, the forms of currency in the financial asset hypothesis, the inadequacy of the financial operations, the rigidization and the temporal or dimensional incongruity of the sources and the destinations of the interactive flows are institutional causal factors of the vulnerability of the network, perceived by network participants by diminishing the reliability of flows that may generate liquidity or solvency risk through volatility of asset prices through the juncture of network nodes [12, SUNDARARAJAN, Arun, 2008], i.e. financial institutions or markets, which may ultimately lead to bankruptcy risk and so on.

Institutional causes of monetary network vulnerability may be:

$\checkmark$ a compositional incompleteness of entities, for example the lack of necessary entities;

$\checkmark$ a failure of connections, cumulative or distributive nodes;

$\checkmark$ o lack of functional loop connectors such as guarantee bodies, trade effects, advisory entities, and network loops to ensure the re-circulation of the inactive, temporary pending currency, such as the locked currency;

$\checkmark$ the degradation of operational synapses, such as the transformation of deposits, due to the interactive gap between collection and placement or currency convertibility due to the institutional irrelevance of monetary forms, such as reserves, surpluses, placements.

The risk of vulnerability is therefore, above all, a risk of institutionalization of the financial network and derives from the network's inadequacy to environmental conditions, to its requirements and needs, and in this respect the direct effect of this network risk, the depreciation of the currency in its form - transactional, interactive, currency risk, is associated with the degradation of these conditions, with the relation between the internal and the external environment.

-The risk of de-synchronization is a risk of the flows, of their interconnection in the network, affecting the interactivity of the network, ie its essence, being formally generated by the institutional regulation and organization of the network, and thus by the way of the network implementation, and functionally, i.e. the activities, responsibilities and competences of the constituent entities [5, DIMITRIU, M. et al., 2017].

Desynchronization refers to the occurrence of any disagreement, of any kind, between the network flows, with the following aspects: gaps, gaps, defects and incompatibilities.

Time spans between cash inflows and outflows, between the formation of monetary resources and liquidity, and their use, transforming them into placements, increasing the stagnation of the coin as an inactive currency. If some gaps are necessary for financial transactions and interactions, most are inertial, institutionally determined, often even regulatory, inducing lasting differences, affecting the fluidity of money, circulation, and currency transformation, usually triggering liquidity and capital risks.

Dimensional differences in the capacity and length of flows, but also in the extensibility and intensity of the financial network. If, for example, there is a discrepancy between the capacity and the length of the collection and placement of flows, the risk of de-synchronization can also generate the liquidity risks, as well as the discrepancy between network extensibility and insensitivity, which will primarily affect the effectiveness of the network, causing a risk of financial asymmetry, concentration and rigidisation associated with the insolvency risk of financial entities that, through contagion, can affect the entire network.

Flow deficiencies due to the circuit of the instruments on the flow, the network velocity, these streams often result in blockages, being partly responsible for the occurrence of the risk of network agglutination, with effects on the network interactivity, determining the liquidity and monetary depreciation, as well as the currency risk [1, SUNDARARAJAN, Arun, 2019].

Instrumental incompatibilities manifested by the inadequacy of the financial instruments to achieve certain goals or functionalities of the network, their non-adaptation to the transited currency 
aggregates (locked currency, reserves, savings, equity, hedge funds, etc.), or, generally speaking, the supply of financial and monetary instruments (checks, cash, cards, accounts, etc.) and the demand, and especially the potential, demand, which expresses the need for economics of instruments, perhaps not yet operational, and why not yet unthinkable.

The risk of de-synchronization induces a negative resonance in the network, in the case of an increased dissonance, the network may enter into "trepidation", the generic expression of this situation, the risk of vibration, negative resonance being the fluctuation, the agitation of the exchange rate, the price, the purchasing power of the coin, on a trend of chronic depreciation [2, BELVAUX, Bertrand, 2011].

The institutional causes of this risk are connected and often dependent on economic, social and political causes (unless we consider monetary policy itself an institution), but it is obvious that the way of building its financial network, its architecture, its institutional dimensions and adequacy, contributes significantly to the emergence and maintenance of this risk.

- The agglomeration risk, correlated with the two previous risks, is manifested through the abundance, segregation and concentration of the currency forms and of the financial instruments on flux, in certain areas of the network, by regionalization, polarization and conjucturing, phenomena with different etiologies, institutional inadequacy of the network, creating favorable conditions, especially through the channel of incapacity, for the occurrence of rate, insolvency, and obviously market, price risks, financial assets, currency.

Very often, this network risk is associated with insufficient networking of specific elements of the network, which will provide certain services to the markets and contribute to strengthening its transparent automata, such as:

$\checkmark \quad$ a continuous counting of network flows, highlighting crowded and relatively free routes, for example, the discrepancy between the interbank and the financial or the pay gap, this metering having a potential for selectivity and potential reorientation;

$\checkmark$ functional and operational adaptation of flows to the concrete requirements of interactivity, by setting up network adapters, analogue clearing houses, transforming financial assets and instruments, and forms of currency according to market requirements, making these adapters an integral part of financial markets (such as adapters), liquidity fluidization (factorial adapters), rate compensation (distributive adapters), etc., taking over some of the current market dysfunctions, such as speculative ones, which distorts some of these adaptation attributes, and redesigning the market by integrating it, strengthening its institutional network automation.

$\checkmark$ in an instrumental conversion, trying to achieve this conversiveness interactivity, the market, as it is conceived and established, is not conversational but marginal or improper, I would say, it is forcing little institutional potential of the network. A conversion market, such as the derivatives market, could be constitutively and institutionally made, in fact, anticipating and conditional this conversion, but often in a speculative environment, denaturating the functions of the currency, of monetary forms [9, MANTA, Otilia, 2018].

Managing this network risk is principally a problem of institutionalization and functionally an issue of evaluation and supervision because the flexibility of the currency, its equitable freedom, should also be found in its capitalized, financially instrumental forms, between currency-trust, it gives omniscence to it, and economic judgment, which usually regulates fragmentarily, capital flows, saved money, contradictions, crisis-generating confrontations that partially reflect the existence of this agglomeration risk with speculative openings [10, ECONOMIDES, Nicholas et al., 2006].

- The risk of detachment and polarization is the specific network risk that suffers from three institutional diseases:

$\checkmark$ ignorance, in the sense of disregard or insufficiency of consideration of the environment, due to the institutional endowment, which gives it some form of knowledge and understanding;

$\checkmark$ vanity, not in the anthropomorphic sense, determined primarily by the approach of currency, of monetary forms, in terms of profit-centered economic reasoning, financial entities considering the currency capitalized as a generator of power and not as a binder between the network and the environment, bidders and coin applicants, the bank currency, and its financial form, which produces wealth, denoting for the most part the functions of the coin, perhaps adapting them to distorted forms 
of authentic currency, based on trust; obviously, vanity is reactive, not adaptive, and that is the case of financial crises, often induced by financial entities, banking in the socio-economic ensemble;

$\checkmark$ esoterism, in the sense of the financial sector, especially the banking sector, being hardly accessible to the uninitiated, this disease being landless, from time immemorial, and partly with constitutive justifications and, we could say, ontological. The coin being something very sensitive and omniscient has been called the blood of society, but it has now become a kind of pathology of appearances, a pathology commanded, authentic, original esoteric, original, disappearing, remaining an esotericism of complications, often unnecessarily functional functional diversions mimetic esotericism, but the more sickly and contagious [11, GRANT, Robert M., 2010].

The risk of detachment is manifested by the separation of the financial network from the socioeconomic environment as a whole, from its real markets, including the health, culture, education, financial network, and sometimes it is in the face of the specific evolution of these human areas how to build up the guiding principles of its configuration and architecture, so that posting induces specific risks in the financial network, such as rate and rate, volatility and lack of real coverage, not speculativearbitrary, generating furious crises at the local level, regional, hard-to-absorb, loss-making and environmental costs, but also liquidity risks, ending up with bankruptcy as well as non-financial entities.

The polarization risk highlights the network's tendency to create concetrative poles, financial centers officially represented by the central bank, which, beyond the coordination and regulatory attributes, becomes a market operator in the name of monetary policy, conferring confidence in the currency, in its purchasing power, but also in operative financial centers, which co-ordinates with money, the financial instruments, the power to influence, to intervene, to sometimes unbalance the markets in the "order" to balance them according to already esoteric goals, or at least selective beneficial [6]. Polarization is a phenomenon common to all networks, from mineral, natural to neural and spiritual, but the polarizing institutionalization of the financial network can have perverse, sometimes unpredictable effects, polarization contributing to accentuating network risks, financial network specificities, to the extent in which polarization does not serve the network, the currency, the trust in the currency, exacerbating, for example, the gain orientation, according to economic reasoning.

A significant effect of postponement and polarization risk, a potential and a real effect, is generating specific devastating risks is the unparalleled expansion of the value of financial flows compared to real flows, most financial flows milling down the currencies, obviously for earnings, for the transfer, rarely converted into real, consuming or investment assets [3, BULEY, Taylor, 2009].

\section{CONCLUSIONS}

The five types of network risks developed above do not cover the whole range of risk potential inherent in the financial network, highlighting only their existence, their specificity and relevance in the monetary space, as well as their institutional determinant etiology. At the same time, the above approach wanted to reveal that the credibility risk is paramount, being the generic network risk, the placement of its currency, its forms and instruments, in a space dominated by economic reasoning, centered on interest and gain, credibility in the currency, the ability of the coin to perform its original functions.

Risk Network, the five types of its defined above are generated by both determinants and conditioning, and they generate direct and indirect effects through specific risks network financial risk network is placed in a structure of interdependencies, of direct and mediated influences [5, DIMITRIU, M. et al., 2017].

Financial market infrastructure plays a central role because financial stability is greatly influenced by the environment in which financial intermediaries operate. As there are cultural differences, there are also structural differences between countries. Nations have a diversity between political and economic systems, legal frameworks and tax structures, which play a central role in the development of their financial systems. Those national influences can certainly interact and certainly affect practices and procedures in the regional financial markets.

Risks of financial instability are likely to occur from time to time and therefore formulate a well articulated strategy to address potential financial imbalances should be high on the agenda of central banks and supervisors [11, GRANT, Robert M., 2010]. Such strategies should cover the following areas: A coherent policy framework at the macroeconomic level to ensure the implementation of a coherent 
macroeconomic policy framework [7, BLIND, Knut, 2004], essential for maintaining financial and monetary stability. The framework should be consistent in achieving macroeconomic objectives and should avoid the accumulation of imbalances that may lead to financial instability.

From the point of view of the personal contributions related to the working hypotheses, we consider that the determinant element that leads us to the definition of the financial network is given by the risk of detachment and polarization and that is also the specific risk of the network. Moreover, as mentioned above, the network is placed in a structure of interdependencies, which causes us to reconsider the direct influences on the new architecture of the financial market, these will be the subject of continuity of our research. At the same time, we consider that the working hypotheses are confirmed due to the fact that both I1.the financial circuit may be represented in the network and I2. The financial markets within the network are integrated are determinants for I3. Flawless links between risks and performance in financial networks, and all these lead us to a current integrated and multipolar financial system.

\section{REFERENCES}

1. SUNDARARAJAN, Arun. Network Effects. [Accesat 11.08.2019]. Disponibil: http://oz.stern.nyu.edu/io/network.html

2. BELVAUX, Bertrand. The Development of Social Media: Proposal for a Diffusion Model Incorporating Network Externalities in a Competitive Environment. In: Recherche et Applications en Marketing. 2011, vol. 26 (3), pp. 7-22. ISSN 2051-5707.

3. BULEY, Taylor. How To Value Your Networks. 2009, july 31. [Accesat 11.08.2019]. Disponibil: https://www.forbes.com/2009/07/31/facebook-bill-gates-technology-securitydefcon.html\#1d48d4ee4cea

4. SHAPIRO, Carl, VARIAN, Hal R. Information Rules. Brighton: Havard Business School Press, 1998. ISBN 0-87584-863-X; ISBN 9780875848631.

5. DIMITRIU, M., MANTA, O. Architecture of Flows and Financial Stocks-Mechanism and Transmission Channels, Flow, Transmitters and Receivers. In: Modelling, Simulation and Applied Mathematics: 2nd international conference, march 26-27 2017. Series: Advances in Intelligent Systems Research. 2017, vol. 132. [Accesat 11.08.2019]. Disponibil: https://www.atlantispress.com/proceedings/msam-17

6. PARKER, Geoffrey, VAN ALSTYNE, Marshall. Two Sided Networks: A Theory of Information Product Design. In: Management Science. 2005, vol. 51 (10). [Accesat 11.08.2019]. Disponibil: https://pubsonline.informs.org/doi/abs/10.1287/mnsc.1050.0400

7. BLIND, Knut. The economics of standards: theory, evidence, policy. Cheltenham-Northampton: Edward Elgar Publishing, 2004. 384 p. ISBN 978-1-84376-793-0.

8. METCALFE, Robert M. It's All In Your Head. 2007, april. [Accesat 11.08.2019]. Disponibil: forbes.com/forbes/2007/0507/052.html

9. MANTA, Otilia. Current Trends of the National Financial Market in the Context of the Global Financial Market. CCFM-INCE, Romanian Academy. 2018, march. [Accesat 11.08.2019]. Disponibil: https://www.researchgate.net/publication/324475305_The_current_trends_of_the_national_fi nancial_market_in_the_context_of_the_global_financial_market

10. ECONOMIDES, Nicholas, KATSAMAKAS, Evangelos. Two-sided competition of proprietary vs. open source technology platforms and the implications for the software industry. In: Management science. 2006, vol. 52 (7). [Accesat 11.08.2019]. Disponibil: http://neconomides.stern.nyu.edu/networks/Economides_Katsamakas_Two-sided.pdf

11. GRANT, Robert M. Contemporary Strategy Analysis. Hoboken: John Wiley\&Sons, 2010. 516 p. ISBN 0-470-74710-2.

12. SUNDARARAJAN, Arun. Local network effects and complex network structure. In: The B.E. Journal of Theoretical Economics. 2008, vol. 7 (1), pp. 1-37. ISSN 1935-1704.

ARTICLE HISTORY

Received 11 September 2019

Accepted 05 December 2019 